\title{
REVOLUSI PENDIDIKAN TARI
}

\author{
Suwarjiya $^{1}$ \\ 1. Dosen Program Studi Pendidikan Seni Tari STKIP PGRI Banjarmasin
}

\begin{abstract}
ABSTRAK
Pendidikan sebagai transformasi budaya dapat dikatakan sebagai kegiatan pewarisan budaya dari satu generasi ke generasi yang lainnya. Pendidikan justru mempunyai tugas menyiapkan peserta didik untuk hari esok dan mentransformasikan nilai budaya sehingga dapat membentuk karakter. Keunggulan yang paling menonjol terhadap pemanfaatan TIK dalam pembelajaran tari adalah pewujudannya divisualisasikan dalam presentasi terbukanya akses pembelajaran tari yang tak terbatas, utamanya terkait dengan persoalan: time, location, speed, person/guru. Artinya dengan model pembelajaran tari e-Learning, perkembangan seni budaya sebagai pembentuk karekter bangsa melalui nilai-nilai tari akan dapat berlangsung secara efektif dan efisien. Regenerasi kepenarian kian mengarah pada pengembangan ide persoalan : time, location, speed, person/guru. Artinya dengan model pembelajaran tari e-Learning, perkembangan seni budaya sebagai pembentuk karekter bangsa melalui nilai-nilai tari akan dapat berlangsung secara efektif dan efisien. Dengan kata lain, regenerasi kepenarian kian mengarah pada pengembangan ide-ide modern. Sehingga penerapan TIK dalam pembelajaran tari dapat dimaanfaatkan pula untuk pengembangan manajemen pendidikan tari ke depannya. Dari model pembelajaran yang terikat oleh persoalan person, time, location, dan speed, kini dengan memanfaatkan TIK persoalan itu time, location, dan speed, kini dengan memanfaatkan TIK persoalan itu dapat diatasi. Dengan memanfaatkan TIK, sangat memungkinkan perkembangan seni budaya tradisi, khususnya seni tari akan terlepas dari sekat-sekat wilayah bahkan akan dapat dipelajari oleh masyarakat internasional. Mereka dapat belajar dengan baik melalui, seperti halnya CD-interaktif atapun software-software pembelajaran tari yang dieksplore melalui internet, dalam bentuk pembelajaran jarak jauh. Maka dapat dikatakan, dengan pemanfaatan TIK, akan dapat terjadi revolusi pendidikan tari.
\end{abstract}

Kata Kunci: Revolusi, Pendidikan, Tari, TIK

\section{PENDAHULUAN}

Sejak adanya manusia di muka bumi ini dengan peradapannya maka sejak itu pula pada hakikatnya ada kegiatan pendidikan dan pengaharan. Berbeda dengan masa sekarang, di mana pendidikan dan pengajaran itu diselenggarakan di sekolah maka pada masa lampau kegiatan dilaksanakan di dalam kelompok-kelompok masyarakat, yang dewasa ini kita sebut dengan istilah pendidikan in formal. 
Dari tonggak sejarah dapat kita lihat bagaimana persoalan-persoalan yang timbul mereka pecahkan. Kita akan mengetahui bagaimana para nabi menyampaikan ajaran-ajaran Tuhan kepada umatnya dengan mengumpulkan sejumlah orang dan kepada mereka diberikan wejangan-wejangan dan ajaran-ajaran Tuhan kepada umatnya keagamaan tentang kebenaran dan keingkaran, tentang yang baik dan yang buruk dan lain-lain. Orang-orang itu dikumpulkan mungkin di atas goa, di atas bukit, di kemah-kemah, atau di dalam bangunan keagamaan yang telah ada pada waktu itu, seperti kuil, gereja, masjid, pesantren dan lain-lain.

Proses pendidikan di Indonesia adalah menggunakan sistem tutur-tinular. Transformasi sistem nilai bergerak dari orang ke orang. Dari orang terdekat, ayah ke pada anak, cucu, sampai dengan kerabat terjauh, proses pendidikan mereka berbentuk nyantrik. Karena itu kemudian terbangun sistem kekerabatan keluarga yang kuat, kesukuan yang kuat hingga bangsa Indonesia memiliki suku-suku bangsa yang beraneka ragam pola kehidupannya. Tahap selanjutnya menggunakan model pembelajaran baca-tulis atau sistem literet. Teks-teks dibuat dengan media daun ataupun benda-benda alam sekitar lainnya yang dapat dijadikan media untuk menulis pesan. Dari masa ini, kita bisa mengetahui perkembangan ilmu pengetahuan dan teknologi bangsa Indonesia berkembang pesat, sampai pada pernah merasakan kejayaan pada jaman Sriwijaya dan Majapahit. Ironis memang, memasuki kehidupan modern pola kemajuan intelektual dan kesadaran akan kehidupan berbangsa bernegara Indonesia tertinggal, kemudian hidup dalam masa penjajahan. Seiring dengan itu, perkenalannya dengan teknologi pendidikan modern (industri kertas dan alat tulis menulis) muncullah tokoh-tokoh nasional yang menjadi aktor intelelektual bangsa. Diantaranya berbentuk pendidikan jarak jauh menggunakan jasa surat menyurat pos sehingga kita mengenal kumpulan surat-surat RA. Kartini "Habis Gelap Terbitlah Terang." dengan kerabat terjauh, proses pendidikan mereka berbentuk nyantrik. Karena itu kemudian terbangun sistem kekerabatan keluarga yang kuat, kesukuan yang kuat hingga bangsa Indonesia memiliki suku-suku bangsa yang beraneka ragam pola kehidupannya. Tahap selanjutnya menggunakan model pembelajaran baca-tulis atau sistem literet. Teks-teks dibuat dengan media daun ataupun benda-benda alam sekitar lainnya yang dapat dijadikan media untuk menulis pesan. Dari masa ini, kita bisa mengetahui perkembangan ilmu pengetahuan dan teknologi bangsa Indonesia berkembang pesat, sampai pada pernah merasakan kejayaan pada jaman Sriwijaya dan Majapahit. Ironis memang, memasuki kehidupan modern pola kemajuan intelektual dan kesadaran akan kehidupan berbangsa bernegara Indonesia tertinggal, kemudian hidup dalam masa penjajahan. Seiring dengan itu, perkenalannya dengan teknologi pendidikan modern (industri kertas dan alat tulis menulis) muncullah tokoh-tokoh nasional yang menjadi aktor intelelektual bangsa. Diantaranya berbentuk pendidikan jarak jauh menggunakan jasa surat menyurat pos sehingga kita mengenal kumpulan surat-surat RA. Kartini "Habis Gelap Terbitlah Terang."

Kini dunia pendidikan di Indonesia sampai pada tahap pemanfaatan Teknologi Informasi dan Komunikasi (TIK). Walaupun TIK secara jaringan telah merambah kesegenap penjuru nasional, akan tetapi dalam hal penerapannya belumlah familiar benar. Apalagi dalam hal pemanfaatannya bagi dunia pendidikan. Mungkin kebanyakan masih asyik berlama-lama menikmati kecanggihan komputer termasuk 
sarana dan prasarananya seperti halnya bermain game dan ber-internet ria. Padahal jelas bahwa kondisi geografis Indonesia yang amat luas serta terbagi atas berbagai propinsi maupun kabupaten tentu merupakan sebuah tantangan dalam pengembangan akses dan peningkatan mutu pendidikan nasional sebagai bentuk kesadaran akan pentingnya peran guru sebagai agen perubahan dan transformator sistem nilai. Artinya, agar kemajuan intelektual peserta didik senantiasa terkontrol oleh sistem nilai. Intelektualitas peserta didik harus senantiasa diimbangi dengan wawasan jatidirinya sebagai bangsa Indonesia yang berbudaya Indonesia. guru sebagai agen perubahan dan transformator sistem nilai. Artinya, agar kemajuan intelektual peserta didik senantiasa terkontrol oleh sistem nilai. Intelektualitas peserta didik harus senantiasa diimbangi dengan wawasan jatidirinya sebagai bangsa Indonesia yang berbudaya Indonesia.

Adanya persentuhan langsung antara pendidik dan peserta didik, pada akhirnya akan menjadi kunci dan faktor penentu dalam penerapan teknologi pendidikan TIK (e-Learning). Mengingat dibanding dengan cara lama, memang ada perbedaan yang signifikan antara sistem e-Learning dengan sistem lama.

Model lama vs E-Learning Pendidikan sebagai proses transformasi budaya merupakan kegiatan pewarisan budaya dari satu generasi ke generasi yang lain. Pendidikan merupakan proses pemanusiaan untuk menjadikan manusia memiliki rasa kemanusiaan, menjadi manusia dewasa, dan manusia seutuhnya agar mampu menjalankan tugas pokok dan fungsi secara penuh dan mengembangkan budaya. Kebudayaan dan pendidikan memiliki hubungan timbal balik sebab kebudayaan dapat dilestarikan dan dikembangkan dengan jalan mewariskan kebudayaan dari generasi ke generasi penerus dengan jalan pendidikan. Pendidikan berbasis budaya menjadi sebuah gerakan penyadaran masyarakat untuk terus belajar sepanjang hayat dalam mengatasi segala tantangan kehidupan yang berubah-ubah dan semakin berat. Selain itu pendidikan memberikan jawaban dan solusi atas penciptaan budaya yang didasari oleh kebutuhan masyarakat sesuai dengan tata nilai dan sistem yang berlaku di dalamnya.

Pendidikan sebagai transformasi budaya dapat dikatakan sebagai kegiatan pewarisan budaya dari satu generasi ke generasi yang lainnya. Pendidikan justru mempunyai tugas menyiapkan peserta didik untuk hari esok dan mentransformasikan nilai budaya sehingga dapat membentuk karakter. Pendidikan tanpa nilai-nilai budaya bagaikan bertepuk sebelah tangan. Pendidikan tanpa orientasi nilai-nilai adalah omong kosong yang mustahil. Karena itulah, tak berlebihan apabila Ary H. Gunawan mendefinisikan pendidikan sebagai proses sosialisasi, yaitu sosialisasi nilai, pengetahuan, sikap, dan keterampilan (Gunawan, 2000).

\section{METODE PENULISAN}

Penulisan makalah ini menggunakan pendekatan kualitatif dengan metode deskriptif. Metode tersebut merupakan cara yang digunakan untuk mendeskripsikan dan menggambarkan secara faktual dan akurat mengenai fakta-fakta yang ada serta hubungan antara fenomena yang diteliti. Metode deskriptif analitis dari fakta yang diperoleh diharapkan dapat menemukan kecenderungan atau kemungkinan adanya fenomena revolusi pendidikan seni tari. 


\section{HASIL DAN PEMBAHASAN}

\section{Revolusi Pendidikan Seni Tari}

Sebagaimana telah disinggung di atas, bahwa tahapan proses pendidikan di Indonesia ada 3 tahapan, yaitu masa tutur-tinular, literet atau baca-tulis, dan sekarang sedang memasuki tahap pemanfaatan TIK. Terkait dengan pembelajaran seni tari, selama ini digunakan 2 model yaitu tutur-tinular dan literet. Karena itu, pembelajaran seni tari hanya dapat berlangsung apabila peserta didik bertemu dengan orang yang bisa menari. Akibatnya, pembelajaran tari di Jawa sejak awal hanya terpusat di lingkungan keraton. Para empu keraton mengajar tari di pendapa-pendapa milik pejabat-pejabat keraton.

Di Banjar, tari berkembang di sanggar-sanggar tari milik para seniman tari dan bentu tarinya mengikuti aliran para seniman yang mengajarkannya seperti AW Sarbaini dengan sanggar Ading Bastari di Barikin, Sanggar Perpekindo Banjarmasin yang identik dengan gaya Drs, Hariyadi Haris dan lain-lain. Dengan kata lain, para seniman tari bentuk tari yang mereka ajarkan memiliki ciri khas berbeda-beda. Itu artinya seni tari tradisi sejak awal memiliki nilai-nilai interpretatif dan kreatif. Bentuk pendidikannya sampai sekarang seperti halnya Program Studi Pendidikan Seni Tari STKIP PGRI Banjarmasin, sanggar-sanggar tari, berlangsung dalam bentuk tatap muka antara guru tari dengan peserta didik. Selanjutnya dapat dijelaskan bahwa yang dimaksud revolusi pendidikan tari dalam tulisan ini adalah adanya kemungkinan bahwa dengan memanfaatkan TIK berbasis android misalnya, orang akan dapat belajar menari tanpa harus bertemu dengan orang yang dapat menari. Artinya, melalui model pembelajaran e-Learning peserta didik dapat belajar tari sendiri tanpa guru.

Tentu saja, sebagaimana dipetakan pada 3 model pembelajaran di atas, masing-masing bentuk pembelajaran memiliki kelemahan dan kelebihan masingmasing. Hal yang paling menonjol adalah persoalan panutan, cara lama tergantung panutannya, cara baru yaitu model e-Learning tanpa panutan.

Keunggulan yang paling menonjol terhadap pemanfaatan TIK dalam pembelajaran tari adalah .. Pewujudannya divisualisasikan dalam presentasi terbukanya akses pembelajaran tari yang tak terbatas, utamanya terkait dengan persoalan: time, location, speed, person/guru. Artinya dengan model pembelajaran tari e-Learning, perkembangan seni budaya sebagai pembentuk karekter bangsa melalui nilai-nilai tari akan dapat berlangsung secara efektif dan efisien. Coba bandingkan dengan sistem pembelajaran sebelumnya yang sangat terikat oleh persoalan : time, location, dan speed. Itupun masih diperhadapkan dengan kualitas orang-perorang yang menjadi panutan tari atau gurunya. Mengingat, dapat dikatakan bahwa dalam proses regenerasi guru tari tidak berlangsung dalam proses kontinyuitas kualitas yang terus menerus meningkat.

Dengan kata lain, regenerasi kepenarian kian mengarah pada pengembangan idepersoalan : time, location, speed, person/guru. Artinya dengan model pembelajaran tari e-Learning, perkembangan seni budaya sebagai pembentuk karekter bangsa melalui nilai-nilai tari akan dapat berlangsung secara efektif dan efisien. Dengan kata lain, regenerasi kepenarian kian mengarah pada pengembangan ideide modern. 
Sebagai gambaran, 2017 terjadi konflik tradisimodern yaitu antara karya sendratari kolosal Ramayana Full Story karya mahasiswa Prodi Tari STKIP PGRI Banjarmasin dianggap tidak sesuai dengan tari tradisi, sehingga setelah pementasn yang disaksikan sekitar 4000 penonton dalam 2 sesi mendapat cemooh. Hal ini dapat ditengarai adanya nilai-nilai pembelajaran tari yang tidak terkomunikasikan secara optimal dalam pendidikan tari. Mengingat, bukankah sejak awal para empu tari juga melakukan pengembangan interpretatif dan kreatif terhadap tari tradisi, sehingga melahirkan aliran-aliran tari. Mengapa interpretasi dan kreativitas dalam Sendra Tari Kolosal Ramayana Full Story dipermasalahkan? Hal demikian tentu dapat dipandang sebagai bentuk kerawanan transformasi budaya yang berkaitan dengan ketidak maksimalnya proses transformasi nilai-nilai pendidikan tari.

\section{Peran TIK dalam Manajemen pendidikan}

Terkait dengan pemanfaatan TIK dalam manajemen pendidikan, dapat diandaikan bahwa apabila sejak dulu telah digunakan TIK dalam proses pendidikan tari, tentu kita sekarang ini masih dapat belajar dengan para empu tari yang terwakili oleh CD-interaktifnya. Artinya kita masih dapat merasakan dan melihat guru-guru tari yang handal di masa lalu, seperti halnya AW Sarbaini, Rustam Effendi, Ibu Yur, Syaiful Akhmmad, M.Pd (Dosen STKIP) dan lain-lain. Keadaan keterputusan itu, saat ini sebenarnya masih bisa diupayakan ketersambungannya. Salah satunya dengan cara memenejemen semua bentuk dokumen peninggalan para empu tari baik yang berupa tulisan, gambar, foto, film/video untuk selanjutnya dikemas menjadi media pembelajaran e-Learning. Dengan demikian penerapan TIK dalam pembelajaran tari dapat dimaanfaatkan pula untuk pengembangan manajemen pendidikan tari ke depannya. Artinya, kedepannya nanti regenerasi kualitas guru tari dapat ditingkatkan secara kontinyu dari generasi ke generasi. Dengan demikian kemajuan pendidikan tari akan berlangsung secara signifikan dari waktu ke waktu. menejemen semua bentuk dokumen peninggalan para empu tari baik yang berupa tulisan, gambar, foto, film/video untuk selanjutnya dikemas menjadi media pembelajaran e-Learning.

Dengan demikian penerapan TIK dalam pembelajaran tari dapat dimaanfaatkan pula untuk pengembangan manajemen pendidikan tari ke depannya. Artinya, kedepannya nanti regenerasi kualitas guru tari dapat ditingkatkan secara kontinyu dari generasi ke generasi. Dengan demikian kemajuan pendidikan tari akan berlangsung secara signifikan dari waktu ke waktu. Terkait dengan upaya-upaya perbaikan yang terus menerus dalam pendidikan tari, maka pemanfaatan TIK dalam perannya sebagai media pendidikan sebaiknya dipahami sebagai suatu bagian integral dari proses pendidikan di sekolah, dan menjadi suatu bidang yang harus dikuasai oleh setiap guru professional (Oemar Hamalik, 1994:1). Selanjutnya pengertian media pembelajaran yang dimaksud adalah segala sesuatu yang dapat digunakan untuk menyalurkan materi pembelajaran dari guru ke siswa sehingga dapat merangsang pikiran, perasaan, perhatian dan minat serta perhatian siswa tari sehingga proses belajar terjadi (lihat Arief S. Sadiman, dkk: 2006:7).

Apabila dihubungkan dengan persoalan pendidikan dan pembelajarannya, maka sebagaimana dinyatakan Achsin, teknologi mempunyai pengertian sebagai perluasan konsep tentang media, di mana teknologi bukan sekedar benda, alat, bahan 
atau perkakas, tetapi tersimpul pula sikap, perbuatan, organisasi dan manajemen yang berhubungan dengan penerapan ilmu (dalam Azhar Arsyad, 2007:5). Adapun teknologi e-Learning yang dimaksud, secara alamiah sering dipasangkan sebagai belajar jarak jauh dan metoda belajar yang fleksibel. Kecuali itu, sebenarnya eLearning juga dapat digunakan sebagai pelengkap pengajaran temu muka. Karena itu dalam pembuatan media e-Learning sebaiknya dapat merangkum keberhasilan dari pengalaman-pengalaman model pembelajaran tari di masa lalu. Misalnya, bagaimana para empu tari dahulu dalam menyampaikan pengajaran tari. Dari pengalaman mereka, setidaknya dapat diperoleh bentuk pengajaran yang baik.

\section{Manfaat TIK dalam Pembelajaran Tari}

Pemanfaatan TIK dalam proses pembelajaran harus senantiasa didudukkan pada kepentingan pendidikan. Karena itu, penting kiranya akan kesadaran guru terhadap tujuan tiap pengajaran sebagaimana dinyatakan Rooijakkers (1980) yaitu menimbulkan atau menyempurnakan pola laku dan membina kebiasaan, sehingga peserta didik trampil menjawab tantangan situasi hidup secara manusiawi; karena itu selalu diperlukan adanya penyegaran. Dari pemahaman itu, kita bisa memahami akan arti pentingnya pemanfaatan TIK dalam pembelajaran sebagai bentuk baru yang menyegarkan. Selanjutnya agar terbangun jalinan mata rantai keberhasilankeberhasilan pembelajaran tari dengan yang sebelumnya, maka dalam pembuatan media pembelajaran e-Learning harus senantiasa bertolak dari pengalamanpengaaman di masa lalu.

Mengingat kualitas pembelajaran tari yang dilakukan para guru-guru terdahulu telah pula menunjukkan hasil yang baik. Misalnya kita bisa berangkat dari pengalaman teknik/metode mengajar Heriyadi Haris dan M. Fery Fauzan (alumni STKIP) yang sekarang melanjutkan mengelola sanggar Posko-La Bastari Kandangan. Dari hasil pembelajarannya, keduanya berhasil melahirkan para penari yang bagusbagus. Menurut Rahmani 2019. teknik/metode mengajar kedua empu tari tersebut dapat dijelaskan sebagai berikut. M. Fery Fauzan selaras dengan kekuatannya sebagai seorang pemain gamelan ia menyajikan materi pelajaran banyak menggunakan tuntunan melalui pola irama karawitan dengan pola irama gerak tari. Bentuknya bisa berupa hitungan atau dalam bentuk menyuarakan kendangannya. Ia dapat menegaskan setiap gerak tari perpaduannya dengan hitungan gerak dan bentuk kendangan tarinya. Dalam hal ini siswa dipacu untuk mengembangkan penalarannya ketika M. Fery Fauzan mendektekan hitungan gerak atau suara kendangan. Contoh gerakan tari diberikan seperlunya, dipadu dengan penjelasan tekniknya, misalnya caranya, patokannya, pengembangannya, dll.

Dalam hal irama tari, M. Fery Fauzan memiliki kesadaran bahwa itu merupakan faktor yang bersifat pembawaan yang dipengaruhi oleh postur tubuh seseorang. Oleh karena itu penyesuaiannya dengan gerak tari, M. Fery Fauzan memberikan kesempatan yang luas kepada siswanya untuk menemukannya sendiri. Artinya dalam pengembangan irama, ia tidak memberikan semacam ikatan yang harus diikuti. Namun demikian kontrol tetap dilakukan, utamanya terkait dengan ukuran dasar atau patokan tarinya, sehingga sangat berpengaruh dalam evaluasinya. Ketatnya evaluasi yang dilakukan secara subyektif tampak pada pemilihan penari 
pada saat pementasan (di Posko-La Bastari). Secara obyektif tampak dari penilaiannya yang cukup ketat dan selektif..

Heritadi Haris, kekuatannya justru terletak pada kemampuannya sebagai penari. Heriyadi Haris dalam menyajikan materi pelajaran banyak menggunakan tuntunan dalam bentuk peragaan, dengan sedikit dilengkapi ketukan gerak. Dalam hal tuntunan hitungan ini Heriyadi Haris sering menggunakan pola ketuk 4/8 untuk menegaskan irama gerak tari. Dalam penyampaian materi Heriyadi Haris cenderung berpola imitatif, yaitu siswa menirukan gerakan-gerakan secara langsung. Kebanggaan Heriyadi Haris sebagai penari tampak dari semangatnya memberikan contoh-contoh gerakan secara utuh, hal inilah yang sekaligus menjadi daya tarik bagi siswanya karena kakaguman dan kesempatannya melihat gerak sesungguhnya.. Oleh karena itu, dalam metode pengajarannya tampak sering mengulang-ulang peragaan yang sama.

Dalam sistem pembelajaran ini siswa dipacu untuk mengembangkan pengamatannya secara cermat karena ia berhadapan langsung dengan teknik dan detail gerak sekaligus. Di satu sisi siswa dapat menangkap detail gerak (wilet), di satu sisi terkadang menimbulkan proses pemahaman yang lama. Keuntungannya, ia bisa menangkap gaya tari Heriyadi Haris secara detail. Oleh karena itu, hasil didikan Heriyadi Haris kemudian cenderung berpola gerak persis seperti apa yang dilakukan Heriyadi haris. Jadi meskipun Heriyadi Haris memberi keleluasaan pula terhadap para siswanya untuk mengembangkan tarinya, ternyata pada ujungnya gaya tari Heriyadi Haris tetap menancap dalam dirinya. Hal itu bisa dimaklumi karena kelekatan mereka dalam meniru setiap detail gerak Heriyadi haris. Adapun mengenai evaluasi, secara subyektif tergantung pada rasa pantas dan luwesnya pembawaan tari. Artinya, ia tidak menganggap patokan sebagai harga mati. Dengan kata lain interpretasi terhadap satu tarian dengan yang lain bisa sangat berbeda patokannya, Dengan mencermati pengalaman guru-buru tari terdahulu, akan diperoleh gambaran bagaimana bentuk pembelajaran tari berlangsung. Pemahaman itu kemudian dapat dipadukan dengan pengalaman pribadi guru dalam mengajar tari. Dengan demikian, akan tercapai bentuk-bentuk pemanfaatan TIK dalam pembelajaran tari yang signifikan. Dalam hal pembuatannya harus dipahami halhal apa yang sebaiknya berbentuk video, hal apa yang sebaiknya berbentuk animasi, penjelasan apa yang sebaiknya dipresentasikan dengan suara, bentuk-bentuk apa yang sebaiknya berupa gambar, dan seterusnya. Dari pengalaman mengajar kedua empu tari di atas kiranya dapat dikemas ke dalam sistem pembelajaran e-Learning melalui bentuk media CD-Interaktif.

Selanjutnya, dalam hal pembuatannya harus dapat mengekspose kelebihankelebihan pemanfaatan TIK dalam pembelajaran tari. Sebaliknya juga harus dapat meminimalisir kelemahan-kelemahannya. Kelemahan dalam pemanfaatan TIK memang bukannya tidak ada, CD-interaktif pembelajaran tari menegaskan bahwa persoalan greget tentu akan sulit diproyeksikan. Mengingat persoalan greget tari, menyangkut detail gerak yang bersumber dari daya ekspresi tari.

Tari Baksa Kembang misalnya, tentu akan memiliki greget yang berbeda dengan gerakan tari Radap Rahayu. Walaupun, sekaran geraknya sama, tetapi antara gerakan tari Baksa Kembang dengan Radap Rahayu akan memiliki greget yang berbeda. Tetapi greget bisa diproyeksikan, misalnya dengan meng-close up pengambilan gambarnya. Karena greget itu sebenarnya sebagaimana halnya 
breakdance, yaitu gerak yang sangat detail. Terkait dengan upaya mengekspose detail gerak tersebut, kini telah dirintis adanya kamera yang dipadukan dengan mikroskop. Karena itu, perwujudan sekecil apapun dari suatu motif atau bentuk dapat diperbesar ke dalam bentuk yang sangat jelas. Bahkan media ini, yaitu kamera yang dipadukan dengan mikroskop, akan sangat membantu bagi pengembangan ide-ide kreatif yang bersumber dari objek-objek yang tidak terlihat oleh mata biasa. setelah mencermati adanya CD-interaktif pembelajaran tari menegaskan bahwa persoalan greget tentu akan sulit diproyeksikan. Mengingat persoalan greget tari, menyangkut detail gerak yang bersumber dari daya ekspresi tari.

Apabila pemanfaatan TIK sedemikian bergunanya bagi kegiatan pembelajaran dan pengembangan manajemen pendidikan, pada gilirannya seperti halnya pembuatan CD-interaktif pembelajaran tari, nantinya akan dapat memicu pertumbuhan adanya industri kreatif dari para guru professional dan ciptaannya CD-interaktif pembelajaran dibeli oleh penerbit terkemuka di Indonesia.

\section{KESIMPULAN}

Menyadari akan arti pentingnya kemajuan, maka pemanfaatan teknologi modern merupakan hal yang tidak bisa ditawar-tawar lagi. Termasuk pemanfaatan TIK dalam pembelajaran dan manajemen pendidikan. Dalam studi kasus terhadap pembelajaran tari ini, terbukti dapat menimbulkan gejala perubahan yang sangat besar dan sangat prinsipil. Dari model pembelajaran yang terikat oleh persoalan person, time, location, dan speed, kini dengan memanfaatkan TIK persoalan itu time, location, dan speed, kini dengan memanfaatkan TIK persoalan itu dapat diatasi. Dengan memanfaatkan TIK, sangat memungkinkan perkembangan seni budaya tradisi, khususnya seni tari akan terlepas dari sekat-sekat wilayah bahkan akan dapat dipelajari oleh masyarakat internasional. Mereka dapat belajar dengan baik melalui, seperti halnya CD-interaktif atapun software-software pembelajaran tari yang dieksplore melalui internet, dalam bentuk pembelajaran jarak jauh. Maka dapat dikatakan, dengan pemanfaatan TIK, akan dapat terjadi revolusi pendidikan tari.

\section{DAFTAR PUSTAKA}

Arief S. Sadiman, 2006. Media Pendidikan, Pengertian, Pengembangan, dan Pemanfaatannya. Jakarta: PT. Raja Grafindo Persada.

Azhar Arsyad, 2007. Media Pembelajaran. Jakarta : PT. Raja Grafindo Persada.

Budi Santosa, 2004. "Pertunjukan Tari Samgita Pancasona Karya Sardono W. Kusuma di RRI Surakarta : Dalam Fenomena konflik Tradisi-Modern Masyarakat Seni Pertunjukan Surakarta Tahun 1970-an" Tesis PPS ISI Yogyakarta.

Oemar Hamalik, 1994. Media Pendidikan. Bandung : PT. Citra Aditya Bakti. 
------. 2001. Proses Belajar Mengajar.Jakarta: PT Bumi Aksara

Pusat Kurikulum Balitbang Kemendiknas. 2010. Pengenbangan Pendidikan Kewirausahaan. Jakarta: Balitbang Kemendiknas.

Supriyoko. 2003. Sistem Pendidikan Nasional dan Peran Kebudayaan Dalam Pembangunan Berkelanjutan. Denpasar: Makalah Seminar Pembangunan Hukum Nasional VIII Dilaksanakan oleh Badan Pembinaan Hukum Nasional Departemen Kehakiman dan Hak Asasi Manusia. RI.

Suwardana, Hendra. 2017. Revolusi Industri 4. O Berbasis Revolusi Mental. JATI UNIK, Vol.1, No.2. Hal. 102-110

Tilaar, H.A.R. 1991. Sistem Pendidikan Nasional yang Kondusif bagi Pembangunan Masyarakat Industri Berdasarkan Pancasila. Jakarta: LIPI.

----- 1999. Beberapa Agenda Reformasi Pendidikan Nasional Dalam Perspektif Abad 21. Magelang: Tera Indonesia.

----- 2000. Pendidikan Baru Pendidikan Nasional. Jakarta: Rineka Cipta. 